\title{
Examination of drought stress of two genotype maize hybrids with different fertilization
}

\author{
Éva Horváth - Péter Fejér- Adrienn Széles \\ University of Debrecen, Faculty of Agricultural and Food Sciences and Environmental Management, \\ Institute for Land Utilisation, Technology and Regional Development, Debrecen \\ horvath.eva@agr.unideb.hu
}

\begin{abstract}
SUMMARY
In the growing season of 2019, we analysed stress resulting from climatic factors on maize hybrids of different genotypes, with the aim of gaining a better understanding of the physiological responses of each hybrid, which might support the elaboration of a cost-effective irrigation plan.

Our experiments were carried out at the Látókép Experimental Station of the University of Debrecen on calcareous chernozem soil in a smallplot long-term field trial with strip plot design. In the scope of the experiment, $N$-fertilizer doses were applied as basic fertilizer and topdressing in addition to the non-fertilized (control) treatment. The 60 and $120 \mathrm{~kg} N /$ ha doses applied as basic fertilizers in the spring were followed by top-dressing in the V6 phenophase with a $+30 \mathrm{~kg} N / \mathrm{ha}$ dose. Measurements were carried out with the involvement of the Renfor early (FAO 320) and Fornad (FAO 420) late maturity hybrids-

The stomata of the plants became more and more closed with the progression of the phenological phases; their stomatal conductance decreased. However, the hybrids responded differently to environmental stress. In the case of the Renfor hybrid, the highest conductance (669 $\mathrm{mmol} / \mathrm{m}^{2-s}$ ) was recorded in the V12 phenophase with the $150 \mathrm{~kg} / \mathrm{ha}$ treatment. The stomata were more open due to the high turgor pressure, allowing plants to evaporate properly. The plant was in its worst physiological condition on $2^{\text {nd }} \mathrm{July}$, at the time of the appearance of the last leaf in the case of the $120 \mathrm{~kg} \mathrm{~N}$ dose $\left(224 \mathrm{mmol} / \mathrm{m}^{2-s}\right)$. The value measured in the V12 phenophase has already shown that the stomata were closing due to the self-regulating system of the plant. It would have been necessary to dispense irrigation water following the measurement. This confirms the finding that water stress can be prevented by measuring stomatal conductance.

In the case of the Fornad hybrid, stomatal conductance was the highest on $12^{\text {th }} \mathrm{June}\left(630 \mathrm{mmol} / \mathrm{m}^{2-s}\right)$ in the $90 \mathrm{~kg} \mathrm{~N} / \mathrm{ha}$ treatment and it was the lowest $\left(183 \mathrm{mmol} / \mathrm{m}^{2-s}\right)$ in $\mathrm{VT}$ (emergence of the last leaf) phenophase in the $60 \mathrm{~kg} \mathrm{~N} / \mathrm{ha}$ treatment. In this case, the appropriate time for applying irrigation water would have been early July, when the conditions for the plants were still adequate. Subsequently, the stomata began to close due to a reduction of the water resources available to them.

There was a significant correlation between soil moisture and stomatal conductance, as well as between temperature and stomatal conductance.
\end{abstract}

Keywords: climate change, maize, stomatal conductance

\section{INTRODUCTION}

Adverse weather extremes caused by climate change, drought and water shortage have significant negative effects on the yield and quality of maize (Mukesh et al., 2017). Water shortage during tasseling (Nagy, 2007) and high temperature during fecundation (Butler and Huybers, 2015) result in significant yield reduction. One of the solutions to adapting to extreme weather is to choose stress-resistant hybrids that withstand drought. These hybrids tolerate high temperatures (Islam et al., 2012; Marton et al., 2012; Jolánkai et al., 2016) and provide adequate yield and quality (Izsáki, 2006; Győri, 2010; Pepó, 2017). At the same time, prevention and timely detection of drought play a key role in cultivation (Jolánkai and Birkás, 2010).

The average water content of the plants is $60-80 \%$ (Martinez et al., 2010) and in order to maintain this water content, the plant needs continuous water uptake throughout the entire vegetation period. Only $1-2 \%$ of the absorbed water is used by the plant, while $98-99 \%$ is evaporated (Jones et al., 2013).

By measuring stomatal conductance, plant stress can be detected even before the onset of symptoms (O'Toole and Cruz, 1980), since water supply, heat and light conditions have a decisive influence on stomatal openness and position (Boldizsár, 2007; Anda and Lőke, 2002; Anda. et al., 2010) and stomatal conductance (Miyashita et al., 2005; Yunpu et al., 2013). The aim is to investigate how hybrids of variable genotypes react to the reduction of soil moisture and heat stress. In addition, to prove that the effects of stress can be demonstrated by examining stomatal conductance before the onset of plant symptoms.

\section{MATERIALS AND METHODS}

Production site description: The examinations were carried out in Hungary, at the Látókép Experimental Station of the University of Debrecen $\left(47^{\circ} 33^{\prime} \mathrm{N}, 21^{\circ}\right.$ 26' S, altitude: $111 \mathrm{~m}$ ), on loess-based, lowland calcareous chernozem soil. The trial is a striped smallplot long-term field trial. The measurements were carried out in 2019 with natural precipitation, using Renfor (FAO 320) early maturity and Fornad (FAO 420) late maturity maize hybrids.

Based on the results of soil analysis in 2012, it can be stated that the average $\mathrm{pH}_{\mathrm{KCl}}$ value of the soil is 6.6, which is considered to be slightly acidic; it is optimal for the nutrient uptake of plants. In the upper layer (20 $\mathrm{cm}$ ) of the soil, Arany's plasticity index is 39 and the 
total amount of water-soluble salts is $0.04 \%$, which means low salt content. The carbonated lime content in the upper $80 \mathrm{~cm}$ of the soil is around $0 \%$, which means that the soil is considered to be lime deficient, but below $100 \mathrm{~cm}$ there is $12 \%$ lime, which indicates that the soil is moderately calcareous. The upper $20 \mathrm{~cm}$ of the soil has a $2.3 \%$ organic matter content, which does not exceed $1.0 \%$ at a depth of $120 \mathrm{~cm}$. The potassium supply of the soil is good and its $\mathrm{P}$ content can be considered moderate.

Experimental details: Field examinations were performed with the Sc-1 Leaf Porometer. It determines air flow from originating from the leaves and stomatal conductance of leaves as a function of the density, size and degree of opening of the stoma. Measurements are made over a period of 30 seconds in the range $0-1000$ $\mathrm{mmol} / \mathrm{m}^{2-\mathrm{s}}$. Measurements were made on the lower, middle and upper leaves, respectively. The average of the values obtained was used to infer the physiological state of the specimens. The TDR soil moisturemeasuring probe was used to determine soil moisture. From the average of three measurements per plot, we could infer the soil moisture status. In the field experiment, in addition to non-fertilized (control) treatment, the $\mathrm{N}$-fertilizer doses were distributed as basic fertilizers and top-dressing. The 60 and $120 \mathrm{~kg}$ $\mathrm{N} / \mathrm{ha}$ doses applied as basic fertilizers in spring were followed by top-dressing in the V6 (six leaf stage) phenophase with a $+30 \mathrm{~kg} \mathrm{~N} / \mathrm{ha}$ dose. The green crop was maize. The maize was sown on 10.04.2019. Measurements were performed on seven separate occasions between $4^{\text {th }}$ June and $16^{\text {th }}$ July, 2019, in nonfertilized (control), $\mathrm{A}_{60},(60 \mathrm{~kg} \mathrm{~N}$ applied as base fertilizer) $\mathrm{A}_{120},(120 \mathrm{~kg} \mathrm{~N}$ applied as base fertilizer) $\mathrm{V6}_{90},\left(\mathrm{~A} 60+\right.$ at 6 leaf stage $30 \mathrm{~kg} \mathrm{~N}$ ) and V6 ${ }_{150}(\mathrm{~A} 120+$ at six leaf stage $30 \mathrm{~kg} \mathrm{~N}$ ) treatments. Evaluation of data was carried out with the SPSS for Windows 21.0 statistical software package by means of linear regression correlation test.

\section{RESULTS AND CONCLUSIONS}

\section{Climatic characterisation of the crop year}

Weather was evaluated on the basis of data measured and recorded by an automatic weather station located in the experimental site. The values were compared to the mean values over the period 19812010 (Nagy, 2019).

In the winter period preceding the 2019 growing season, there was little rainfall (only $93.7 \mathrm{~mm}$ ), which was $113.3 \mathrm{~mm}$ below the average. As a result, the replenishment of the deeper soil layers was not satisfactory. The total amount of precipitation in the 2019 growing season $(365 \mathrm{~mm})$ was $19 \mathrm{~mm}$ above the average $(346 \mathrm{~mm})$.

In June, precipitation was $19 \mathrm{~mm}$ below the mean values $(66 \mathrm{~mm})$. The mean monthly temperature was $21.9^{\circ} \mathrm{C}$; especially the middle of the month was warm (Figure 1). Maize is less susceptible to drought and extreme high temperatures during this period than before and later during the silking and ripening periods.

Figure 1: Air temperature and the amount of rainfall during the growing season of maize, 2019

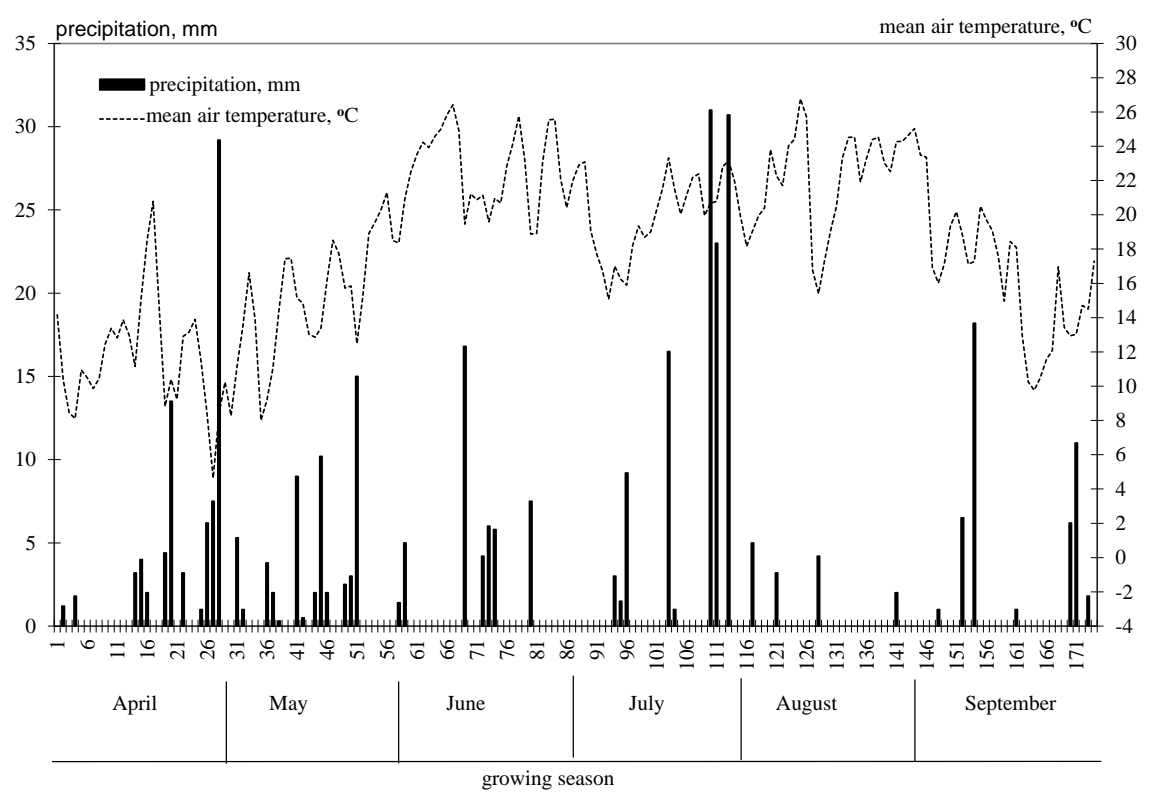

The dry period continued in early July, with colder than normal weather in the middle of the month, which mitigated the adverse effects of the already reduced level of soil moisture. According to Gombos and Nagy (2019), the mean temperature in July $\left(21.1^{\circ} \mathrm{C}\right)$ has never been this low in the last 10 years. There was significant rainfall in the second half of the month. Nearly half of the precipitation fell in 2 days at the end of July (30 and $31 \mathrm{~mm}$ ), the total amount of precipitation of the month was $116 \mathrm{~mm}$. This amount was significantly higher than the average of multiple years. However, in terms of the phenological 
development of maize, this amount of precipitation arrived somewhat late. August was extremely dry, with only $14 \mathrm{~mm}$ of rainfall, much below the average (49 $\mathrm{mm})$.

Development of the stomatal conductance of different genotype hybrids

Within the period of $4^{\text {th }}$ June and $16^{\text {th }}$ July the conductance varied over a wide range. The lowest value of the interval was $183 \mathrm{mmol} / \mathrm{m}^{2-\mathrm{s}}$ while the highest value was $669 \mathrm{mmol} / \mathrm{m}^{2-s}$. Based on the first stomatal conductance measurement ( $4^{\text {th }}$ June $)$ the environmental conditions were adequate for maize hybrids in terms of plant stress. Lower stomatal conductance was observed in the case of the $60 \mathrm{~kg} \mathrm{~N} / \mathrm{ha}$ treatment, but it was recorded at differed nutrient levels for each examined hybrid. In the case of the Fornad hybrid it was recorded in the $150 \mathrm{~kg} \mathrm{~N} / \mathrm{ha}$ treatment (413 $\left.\mathrm{mmol} / \mathrm{m}^{2-\mathrm{s}}\right)$ while for the Renfor hybrid in the control $\left(406 \mathrm{mmol} / \mathrm{m}^{2-\mathrm{s}}\right)$. However, the highest value developed inversely, because the most appropriate environmental condition at the time for the Fornad hybrid was in the non-fertilized treatment (590 $\mathrm{mmol} / \mathrm{m}^{2-\mathrm{s}}$ ) while for the Renfor hybrid in the $150 \mathrm{~kg}$ $\mathrm{N} /$ ha treatment $\left(544 \mathrm{mmol} / \mathrm{m}^{2-\mathrm{s}}\right)$ (Figure 2-3).

Figure 2: Stomatal conductance of the Fornad (FAO 420) maize hybrid, 2019

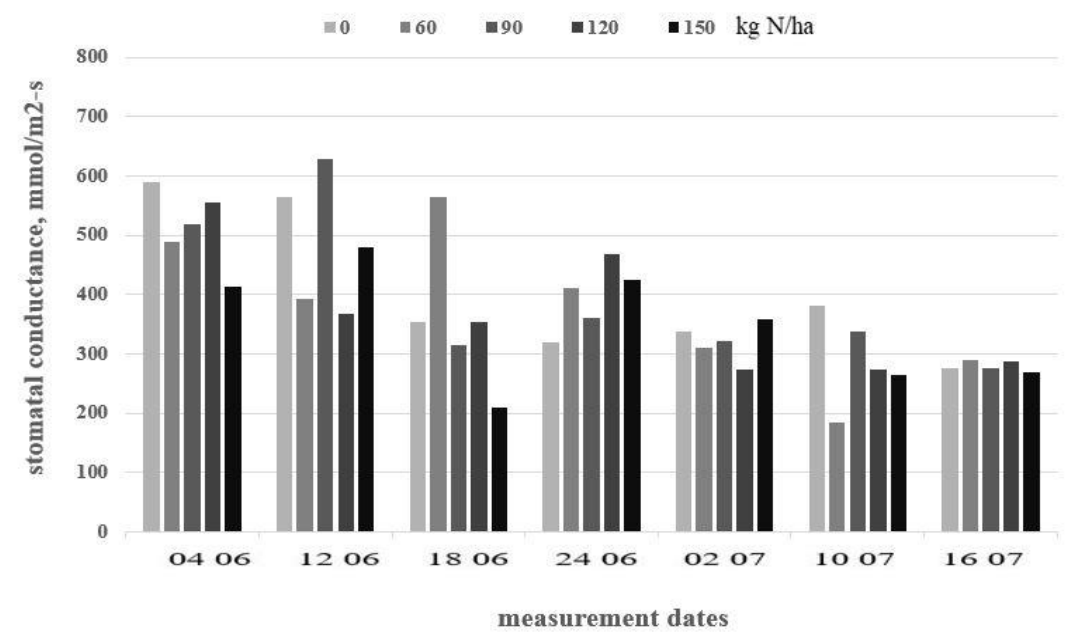

Figure 3: Stomatal conductance of the Renfor (FAO 320) maize hybrid, 2019

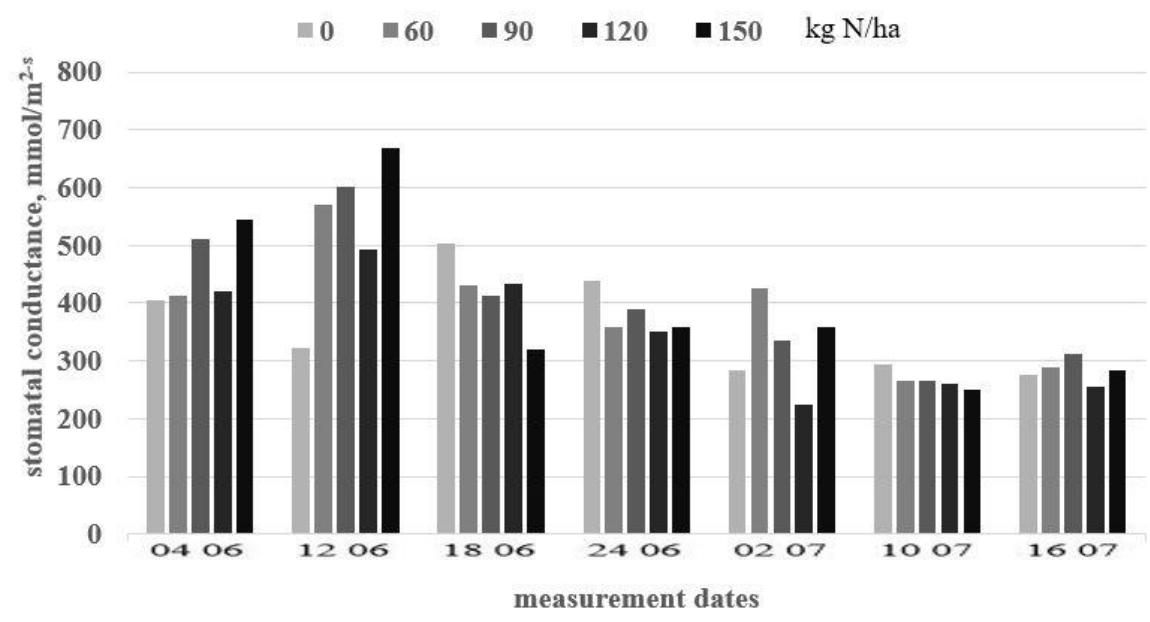

On the second measurement date (12 ${ }^{\text {th }}$ June), the lowest value $\left(323 \mathrm{mmol} / \mathrm{m}^{2-s}\right)$ for the Renfor hybrid was recorded in the control treatment, while the highest stomatal conductance was measured in the $150 \mathrm{~kg} \mathrm{~N}$ dose treatment. The Fornad hybrid reacted differently to environmental conditions, because its highest stomatal conductance $\left(629 \mathrm{mmol} / \mathrm{m}^{2-s}\right)$ was measured in the case of the $90 \mathrm{~kg} \mathrm{~N}$ treatment.

The measurement that took place six days later $\left(18^{\text {th }}\right.$ June) showed that there was a stress situation for both 
hybrids in the $150 \mathrm{~kg} \mathrm{~N} /$ ha treatment, which is indicated by low stomatal conductance. (the plant was exposed to heat and water stress due to decreasing soil moisture and high temperatues). However, the data also show that the Renfor hybrid, which has a shorter breeding period had a better stomatal conductance (319 $\left.\mathrm{mmol} / \mathrm{m}^{2-\mathrm{s}}\right)$ than the Fornad hybrid $\left(210 \mathrm{mmol} / \mathrm{m}^{2-\mathrm{s}}\right.$, which has a longer breeding period. The best physiological condition of the plants was recorded in the control $\left(503 \mathrm{mmol} / \mathrm{m}^{2-s}\right)$ for the Renfor hybrid and in the $60 \mathrm{~kg} \mathrm{~N} /$ ha treatment for the Fornad hybrid.

Different properties of the hybrids showed themselves on the basis of the conductance measured in the V12 (12 leaf) phenological phase of maize $\left(24^{\text {th }}\right.$ June). The Renfor hybrid had the least stress (heat and water stress) in the control treatment, whereas the Fornad hybrid had the most stress in the same treatment. The most suitable environmental condition was in the $120 \mathrm{~kg} \mathrm{~N} /$ ha treatment $\left(468 \mathrm{mmol} / \mathrm{m}^{2-\mathrm{s}}\right)$.

The stomatal conductance measured at the time of the appearance of the last leaf ( $2^{\text {nd }}$ July) showed that both hybrids had the highest stress in the $120 \mathrm{~kg} \mathrm{~N} / \mathrm{ha}$ treatment. The extent of the stress situation varied between hybrids. The plant stress situation was higher in the case of the Renford hybrid $\left(243 \mathrm{mmol} / \mathrm{m}^{2-\mathrm{s}}\right)$ than in the case of the Fornad hybrid $\left(274 \mathrm{mmol} / \mathrm{m}^{2-\mathrm{s}}\right)$.

In the VT (last leaf appears) phenological phase by the emergence of the last leaf, the Fornad hybrid was under the most stress in the $60 \mathrm{~kg} \mathrm{~N} / \mathrm{ha}$ treatment with a conductance value of $183 \mathrm{mmol} / \mathrm{m}^{2-\mathrm{s}}$. This was the lowest stomatal conductance value during the examined period. The stomatal activity showed that the most optimal condition for both hybrids was in the control treatment.

Following the R1 phenophase, the two hybrids had approximately the same stomatal conductance, ranging from $255 \mathrm{mmol} / \mathrm{m}^{2-s}$ to $313 \mathrm{mmol} / \mathrm{m}^{2-s}$.

In summary, it can be stated that the stomata of the plants became more and more closed with the progression of the phenological phases and thus their stomatal conductance decreased. However, the hybrids responded differently to environmental stress. In the case of Renfor (an early maturity hybrid), the highest conductance was recorded in the $150 \mathrm{~kg} \mathrm{~N} / \mathrm{ha}$ treatment of the V12 phenological phase $\left(669 \mathrm{mmol} / \mathrm{m}^{2-s}\right)$. The plant was in its worst physiological condition on $2^{\text {nd }}$ July, when the last leaf appeared $\left(224 \mathrm{mmol} / \mathrm{m}^{2-\mathrm{s}}\right)$ in the $120 \mathrm{~kg} \mathrm{~N}$ dose treatment. However, closing of the stomata was detectable already on the basis of the values measured in the V12 phenophase. Following the measurement, it would have been necessary to apply irrigation water to avoid water stress. All of the above confirm the finding that water stress can be prevented by measuring stomatal conductivity.

The late maturity Fornad hybrid had the highest conductance on $12^{\text {th }}$ June $\left(630 \mathrm{mmol} / \mathrm{m}^{2-\mathrm{s}}\right)$ in the $90 \mathrm{~kg}$ $\mathrm{N} / \mathrm{ha}$ treatment, while the lowest value (183 $\mathrm{mmol} / \mathrm{m}^{2-\mathrm{s}}$ ) was measured in the VT phenophase in the $60 \mathrm{~kg} \mathrm{~N} / \mathrm{ha}$ treatment. In this case, the appropriate time for the irrigation water to be applied would have been early July, when the conditions for the plants were still adequate. Subsequently, the stomata began to close due to a reduction of available water resources.

\section{Effect of soil humidity and air temperature on stomatal conductance}

Linear regression was used to examine the correlation between soil humidity and stomatal conductance, which showed a significant correlation (Figure 4). The obtained results are in accordance with Miyashita et al. (2005) who found that the responses of stomata are closely related to soil moisture content. Water deficiency of soil causes the closing of the stomata. As the phenological phases progressed, soil humidity decreased and became a limiting factor, the plant became under water stress, and stomatal conductance decreased. In both hybrids, stomata were closed to reduce plant transpiration.

There was also a significant correlation between temperature and stomatal conductance (Figure 5). As the temperature increased, the stomata of the plants were closing, resulting in a lower conductance value.

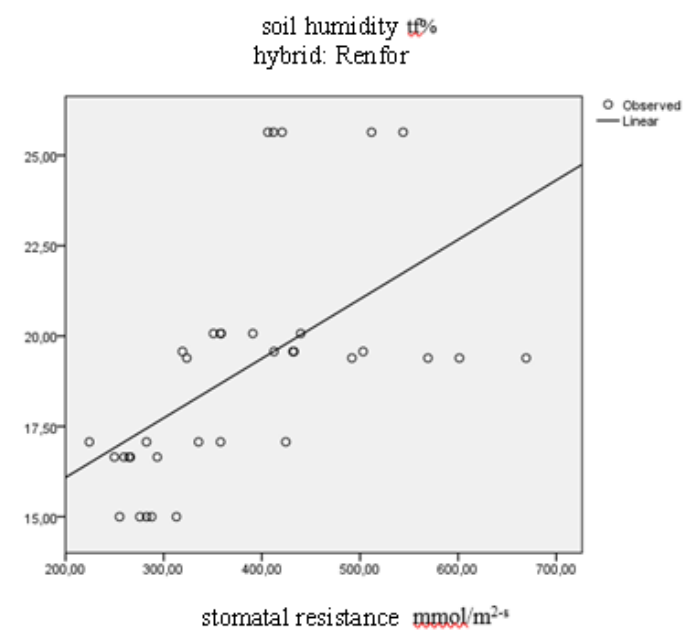

soil humidity to 


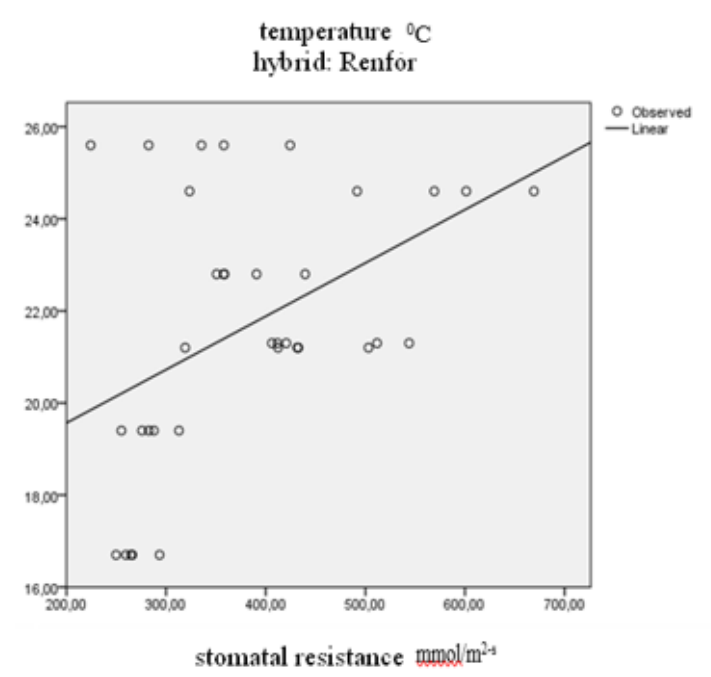

\section{ACKNOWLEDGEMENTS}

The research was financed by the Higher Education Institutional Excellence Programme (NKFIH-11506/2019) of the Ministry of Innovation and Technology

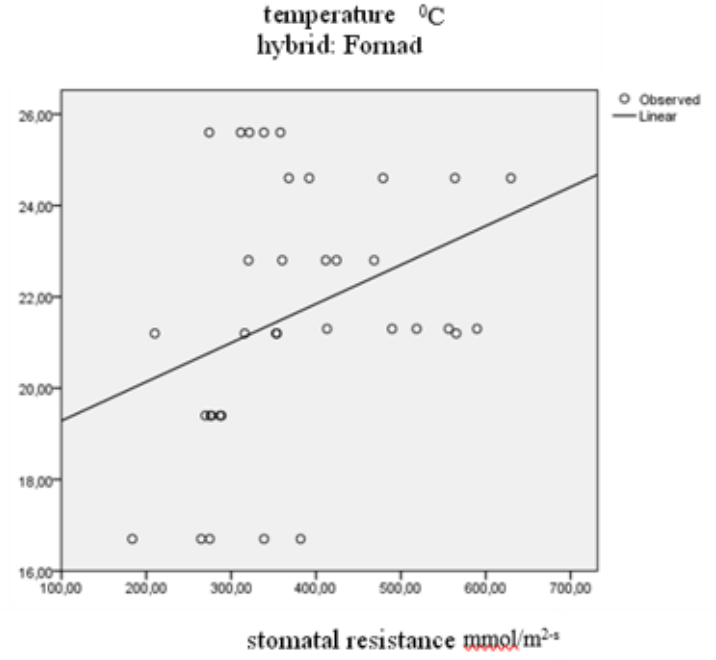

in Hungary, within the framework of the $4^{\text {th }}$ thematic programme of the University of Debrecen, and the projects "GINOP-2.2.1-15-2016-00001 - Developing a scale-independent complex precision consultancy system" and "EFOP-3.6.3-VEKOP-16-2017-00008".

\section{REFERENCES}

Anda, A.-Kocsis, T.-Tőkei, A.-Varga, L. (2010): Agrometeorológiai és klimatológiai alapismeretek 140.

Anda, A.-Löke, Zs. (2002): Stomatal resistance investigations in maize. Keszthely, Veszprém University, Georgikon Faculty of Agronomy, Keszthely, Department of Soil and Water Proceedings of the $7^{\text {th }}$ Hungarian Congress on Plant Physiology S5-04).

Boldizsár, A. (2007): Párolgás és mikroklíma vizsgálatok Balaton nádállományban, Keszthely,79.

Butler, E. E.-Huybers, P. (2015): Variations in the sensitivity of US maize yield to extreme temperatures by region and growth phase. Environmental Research Letters. 10: 3. (March 1).

Gombos, B.-Nagy, J. (2019): Az időjárás értékelése kukorica (Zea mays L.) tartamkísérletek eredményei alapján. Növénytermelés. 68. 2: 5-23.

Győri, Z. (2010): Corn: characteristics and quality requirements, [In: Wrigley, C. W.-Batey, I. L. (eds.) Cereal grains: Assessing and managing quality. Oxford, Cambridge: CRC Press - Woodhead Publishing Limited, 183-211.

Islam, A.-Ahuja, L. R.-Garcia, L. A.-Ma, L.-Saseendran, A. S.Trout, T .J. (2012): Modeling the impacts of climate change on irrigated corn production in the Central Great Plains. Agricultural Water Management. 110: 94-108.

Izsáki, Z. (2006): Effect of nitrogen supplies on protein content and amino acid composition in maize (Zea mays L.) kernels. Cereal Research Communications. 34. 1: 497-500.

Jolánkai, M.-Birkás, M. (2010): Szárazodás, aszály, növénytermelés. „KLÍMA-21” Füzetek. 59. 26-31.

Jolánkai, M.-Tarnawa, Á.-Horváth, Cs.-Nyárai, H. F.-Kassai, M. K. (2016): Impact of climaticfactors on yield quantity and quality of grain crops. Időjárás/Quarterly Journal of The Hungarian Meteorological Service. 120. 1: 73-84.

Jones, R.-Ougham, H.-Thomas, H.-Waaland, S. (2013): The Molecular Life of Plants. Wiley-Blackwell, Chichester, West Sussex, UK, 567.

Martinez, S.-Olmos, I.-Carballo, J.-Franco, I. (2010): Quality parameters of Brassica spp. grown in northwest Spain. International Journal of Food Science and Technology. 45: 776783.

Marton, L. Cs.-Árendás, T.-Berzsenyi, Z. (2012): Martonvásári kukorica hibridek a szárazságban. Martonvásár. 24. 2: 4-7.

Miyashita, K.-Tanakamaru, S.-Maitani, T.-Kimura, K. (2005): Recovery responses of photosynthesis, transpiration and stomatal conductance in kidney bean following drought stress Enviromental and Experimental Botany, 53. 2: 205-214.

Mukesh, D. B.-Silvia, S.-Justin, S. (2017): Projecting corn and soybeans yields under climate change in a Corn Belt watershed. Agricultural Systems. 152. C: 90-99.

Nagy, J. (2007): Kukoricatermesztés. Akadémiai Kiadó. Budapest. 393.

Nagy, J. (2019): Komplex talajhasználati, víz- és tápanyaggazdálkodási tartamkísérletek 1983-tól a Debreceni Egyetemen. Növénytermelés. 68. 3: 5-28.

O'Toole, J. C.-Cruz, R. T. (1980): Response of Leaf Water Potential, Stomatal Resistance, and Leaf Rolling to Water Stress The International Rice Research Institute, P.O. Box 933.

Pepó, P. (2017): Tartamkísérletek mint a klímaváltozás indikátorai. Növénytermelés. 66. 3: 33-46.

Yunpu, Z.-Ming, X.-Ruixing, H.-Shuai, Q.-Zhu, O. (2013): Effects of experimental warming on stomatal traits in leaves of maize (Zea may L.) 3095-3111. 
